\title{
Effects of sulphur dioxide on leaf photosynthesis: the role of temperature and humidity
}

\author{
M. J. Kropff, W. L. M. Smeets, E. M. J. Meijer, A. J. A. van der Zalm and E. J. Bakx
}

Kropff, M. J., Smeets, W. L. M., Meijer, E, van der Zalm, A. J. A. and Bakx, E. J., 1990. Effects of sulphur dioxide on leaf photosynthesis: the role of temperature and humidity. - Physiol. Plant. 80: 655-661.

The effect of temperature and humidity on $\mathrm{SO}_{2}$-induced photosynthetic depression
was determined in gas exchange experiments with leaves of Vicia faba, L. Stomatal
behaviour was sensitive to humidity resulting in higher uptake rates of $\mathrm{SO}_{2}$ and
stronger reductions of photosynthesis at low VPD (vapour pressure deficit). After a
fumigation period of $2 \mathrm{~h}$, when the photosynthetic rate had stabilized, photosynthesis
of leaves exposed to $\mathrm{SO}_{2}$ at $8^{\circ} \mathrm{C}$ was reduced much more than at $18^{\circ} \mathrm{C}$ at the same rate
of $\mathrm{SO}_{2}$ uptake. Data analysis with a mechanistic model revealed that this effect was
due to the slower rate of $\mathrm{S}(\mathrm{IV}$ ) oxidation at lower temperatures, resulting in higher
accumulation of $\mathrm{S}(\mathrm{IV}$ ) and thus stronger reduction of photosynthesis. These results
were confirmed by experimental analyses of the $\mathrm{S}(\mathrm{IV}$ ) concentration in leaves follow-
ing fumigation, which showed that more $\mathrm{S}(\mathrm{IV})$ accumulated in leaves exposed at a
lower temperature. This may explain the high sensitivity of plants exposed to SO
under winter conditions, when both VPD and temperature are low. Key words - Model, photosynthesis, $\mathrm{SO}_{2}$, stomata, sulphur dioxide, sulphur metabolism.

M. J. Kropff (corresponding author), Dept of Theoretical Production Ecology, Agricultural Univ., P. O. Box 430, 6700 AK Wageningen, The Netherlands, W. L. M. Smeets, Dept of Air Pollution, Agricultural Univ., P. O. Box 8129, 6700 EV Wageningen, The Netherlands; A. J. A. van der Zalm, E. M. J. Meijer and E. J. Bakx, Research Inst. for Plant Protection, P.O. Box 9060, 6700 GW Wageningen, The Netherlands.

\section{Introduction}

$\mathrm{SO}_{2}$ effects on plant growth depend upon the environmental conditions at which the plants are grown (see reviews Unsworth and Ormrod 1982, Hällgren 1984, Winner et al. 1985). It has been demonstrated that depressing $\mathrm{SO}_{2}$ effects on plant growth were most severe during winter periods, when temperature and irradiance are low and humidity is high (Cowling and Lockyer 1978, Davies 1980, Whitmore and Mansfield 1983, Baker et al. 1986, 1987). The reported growth reductions are at least partly due to direct effects on photosynthesis and/or respiration, because no strong reductions in leaf area were detected (Whitmore and Mansfield 1983, Baker et al. 1986, 1987).

The environmental conditions in winter (low temperature, low irradiation, high humidity) may directly in- fluence the uptake, metabolism and effects of $\mathrm{SO}_{2}$ metabolites on photosynthesis. McLaughlin and Taylor (1981) demonstrated that pollutant uptake is significantly higher when air humidity is high, which can be understood from the well-known observation that stomatal behaviour depends upon air humidity (Losch and Tenhunen 1981, Morison 1987). When $\mathrm{SO}_{2}$ dissolves in the aqueous phase of the leaf, the sulphite and bisulphite formed are quickly oxidized to sulphate (Miller and Xerikos 1979, Alscher et al. 1987). The rate of S(IV) oxidation in aqueous solutions is very sensitive to temperature (Martin 1984). When sulphite oxidation is slowed at low temperatures in cellular solutions, more toxic S(IV) compounds will accumulate. Because photosynthetic depression is related to the S(IV) concentration (Miller and Xerikos 1979, Alscher et al. 1987, Kropff 1989a), stronger reductions of photosynthesis

Received 27 June, 1990 
can be expected at lower temperatures. However, the role of temperature in $\mathrm{SO}_{2}$ uptake, $\mathrm{SO}_{2}$ metabolism in the leaf and its implications for $\mathrm{SO}_{2}$ effects on photosynthesis has not yet been analysed.

In this study influence of both humidity and temperature on the effect of $\mathrm{SO}_{2}$ on leaf photosynthesis was determined by gas exchange measurements, taking into account the strong relation between temperature and VPD. The physiological backgrounds behind the effect of these environmental factors on $\mathrm{SO}_{2}$ induced photosynthetic depression were analysed using a model for foliar $\mathrm{SO}_{2}$ metabolism in the leaf and effects of $\mathrm{SO}_{2}$ metabolites on photosynthesis (Kropff 1987, 1989a,b). This theoretical analysis was evaluated with experimental data on the S(IV) content of leaves, exposed to $\mathrm{SO}_{2}$ at two temperatures.

Abbreviations - PAR, photosynthetically active radiation PPFD, photosynthetic photon flux density $\left(\mu \mathrm{mol} \mathrm{m} \mathrm{m}^{-2} \mathrm{~s}^{-1}\right)$; Rubisco, ribulose-1,5 bisphosphate carboxylase-oxygenase; $\mathrm{S}(\mathrm{IV}),\left(\left[\mathrm{SO}_{2}\right] \mathrm{aq}+\left[\mathrm{HSO}_{3}^{-}\right]+\left[\mathrm{SO}_{3}{ }^{2-}\right]\right), \mathrm{TCM}$, tetra chlorine mercurate.

\section{Material and methods \\ Plant material}

Broad bean plants (Vicia faba L. cv. Minica) were grown in a greenhouse at $16^{\circ} \mathrm{C}$ and $60-80 \%$ RH. Artificial supplementary illumination (Philips fluorescence 33RS) provided a photoperiod of $16 \mathrm{~h}$. Measurements were taken on the youngest fully unfolded leaves and started when the plants had about 10 leaves.

\section{Experimental equipment}

Materials which have been used for the construction of existing systems for measurement of photosynthesis absorb or react with pollutants like $\mathrm{SO}_{2}$ and $\mathrm{O}_{3}$ (van Hove et al. 1988). Quick changes in pollutant concentrations cannot be obtained and analysis of the rate of foliar pollutant uptake is impossible in these systems. Another problem is the cooling system in which water vapour often condensates, readily absorbing pollutants like $\mathrm{SO}_{2}$. To overcome these limitations a new system for gas exchange analysis during exposure to air pollutants at low concentrations was designed. This computer controlled system consisted of an air supply unit, two leaf chambers and a unit for gas analysis.

Air was dried and purified by passing the air through several filters, containing molecular sieves for removal of $\mathrm{H}_{2} \mathrm{O}$ and $\mathrm{CO}_{2}$ (Gietart, Hengelo), active charocal (RL II-Norit), and a molecular sieve 5A. Air was mixed with $\mathrm{CO}_{2}$ from a cylinder by mass controllers. Air humidity was controlled by injection of water vapour into the air flow with computer controlled ultrasonic nebulizers (modified Heyer, USE 77) with a droplet size of $0.5-4 \mu \mathrm{m}$. Aerosols were removed from the air flow by a series of static mixers (Sulzer). Humidity in the chamber could be changed very rapidly (within a few minutes), without affecting the chamber temperature. The humidified air was mixed in a teflon manifold with $\mathrm{SO}_{2}$ using thermal mass flow controllers (Brooks instruments). $\mathrm{SO}_{2}$ was supplied from a cylinder containing a gas mixture of $1000 \mathrm{ppm} \mathrm{SO}_{2}$ in $\mathrm{N}_{2}$. All tubing and mixing units in contact with $\mathrm{SO}_{2}$ were constructed from teflon or glass. These materials have a relatively low absorption capacity for pollutants and hardly react with the pollutants. All processing was controlled by a Hewlett Packard personal computer (HP 9122) in combination with a data acquisition unit (HP $3497 \mathrm{~A}$ ).

The leaf chamber was illuminated by a combination of high pressure vapour lights [two SON-T (sodium) and three HPI-T (iodine) lights, each $400 \mathrm{~W}$ (Philips)], yielding a maximum PPFD of $1400 \mu \mathrm{mol} \mathrm{m}^{-2} \mathrm{~s}^{-1}$, equal to about $300 \mathrm{~J} \mathrm{~m}^{-2} \mathrm{~s}^{-1} \mathrm{PAR}$. Running cold water through a water bath between the light source and leaf chamber reduced the heating of the chamber. PPFD was measured by a PAR quantum sensor (Technical and Physical Research Service, Wageningen). Air humidity in the chamber was measured by Rotronic hygrometers and the difference in water vapour concentration between the inlet and the outlet of the chamber was measured with an infrared gas analyser (ADC $225 \mathrm{Mk} 3$ ). $\mathrm{CO}_{2}$ concentration at the inlet of the chamber was measured with an infrared gas analyser (ADC D6Y34H). The difference in $\mathrm{CO}_{2}$ concentration between chamber inlet and outlet was measured by a second $\mathrm{CO}_{2}$ analyser (ADC $225 \mathrm{Mk} 3$ ). $\mathrm{SO}_{2}$ concentrations at the inlet and the outlet of two chambers were analysed using a TECO $43 \mathrm{~A} \mathrm{SO}_{2}$ monitor. Samples for the analysis of $\mathrm{H}_{2} \mathrm{O}, \mathrm{CO}_{2}$ and $\mathrm{SO}_{2}$ were drawn from the main air lines entering and leaving the chambers by pumps.

The flow rate of the air through the system was 15.51 $\min ^{-1}$, giving a residence time of the air in the chamber of $0.54 \mathrm{~min}$. Air in the leaf chamber was mixed by recirculation through a heat-exchanger, bathed in alcohol and temperature controlled by a cooling unit (Braun Frigro mix R), which was modified to permit computer control. A teflon fan recirculated the air at a flow rate of $8001 \mathrm{~min}^{-1}$, which resulted in a low boundary layer resistance $\left(15 \mathrm{~s} \mathrm{~m}^{-1}\right.$ for $\left.\mathrm{H}_{2} \mathrm{O}\right)$. All data were collected every 5 min by the $\mathrm{HP}$ microcomputer. Rates of $\mathrm{SO}_{2}$ uptake, transpiration and photosynthesis were calculated from the difference in the concentration between inlet and outlet of the leaf chamber and the leaf area. Stomatal resistance and internal $\mathrm{CO}_{2}$ concentration were calculated according to Goudriaan and van Laar (1978).

\section{Experimental procedure}

The influence of $\mathrm{SO}_{2}$ at various combinations of temperature, PPFD and air humidity on photosynthesis was measured for individual leaves of $V$. faba. The effect of temperature $\left(8\right.$ and $18^{\circ} \mathrm{C}$ ) was studied at two levels of 
radiation (PPFD of 450 or $900 \mu \mathrm{mol} \mathrm{m} \mathrm{m}^{-2} \mathrm{~s}^{-1}$ ) at $70 \%$ RH. The effect of air humidity $(30,50$ and $70 \% \mathrm{RH})$ was studied at a PPFD of $900 \mu \mathrm{mol} \mathrm{m}{ }^{-2} \mathrm{~s}^{-1}$, at $18^{\circ} \mathrm{C}$. At $8^{\circ} \mathrm{C}$, photosynthesis was light saturated at $450 \mu \mathrm{mol} \mathrm{m}^{-2}$ $\mathrm{s}^{-1}$, and at $18^{\circ} \mathrm{C}$ photosynthesis was saturated at 900 $\mu \mathrm{mol} \mathrm{m}-2 \mathrm{~s}^{-1}$. Depending on the treatment, $\mathrm{SO}_{2}$ concentrations ranged from 350 to $1500 \mu \mathrm{g} \mathrm{SO}_{2} \mathrm{~m}^{-3}$, in order to obtain reductions in photosynthesis in the range of $10-30 \%$, necessary for reliable estimation of biochemical parameters with the model (Kropff 1989b). The average $\mathrm{CO}_{2}$ concentration of the ingoing air was 345 ppm.

Leaf thickness was determined by measuring both leaf area and volume. The leaf volume was measured by submerging the leaf in a measuring glass filled with water.

Two plants were placed in controlled climate rooms in the afternoon previous to the day the measurements were conducted, to allow adaptation to the experimental conditions (temperature and humidity). The youngest fully unfolded leaf was enclosed in a leaf chamber. The light intensity was gradually increased to the desired PPFD of 450 or $900 \mu \mathrm{mol} \mathrm{m}^{-2} \mathrm{~s}^{-1}$. When rates of photosynthesis were stable, the enclosed leaf of one of the plants was fumigated for ca $2 \mathrm{~h}$. The other plant was used as a control. Photosynthesis and transpiration were measured during the fumigation period and a subsequent recovery period of ca $2 \mathrm{~h}$.

\section{Model analysis of experimental data}

A model for foliar $\mathrm{SO}_{2}$ uptake, $\mathrm{SO}_{2}$ metabolism in the leaf and effects of $\mathrm{SO}_{2}$ metabolites on photosynthesis (Kropff 1989a,b) was used to analyse the biochemical processes determining temperature effect on the depression of photosynthesis by $\mathrm{SO}_{2}$. Two model parameters determine the magnitude of $\mathrm{SO}_{2}$ effects on photosynthesis: the time coefficient for S(IV) oxidation $\left(\tau_{2}, s\right)$ and a sensitivity parameter $(k)$, which describes the reduction of photosynthesis in relation to the $S$ (IV) concentration in the leaf (mmol S(IV) $\left.1^{-1}\right)^{-1}$ (Kropff 1989a). These two parameters can be estimated by fitting the model to data on the time course of relative photosynthesis during a fumigation period and a subsequent recovery period (Kropff 1989b). In the calculation of the parameter values data on leaf thickness and rate of photosynthesis and stomatal resistance before the onset of fumigation are used. This procedure enables the separation of stomatal (effects on uptake rate of $\mathrm{SO}_{2}$ ) and non-stomatal effects (effects on $\mathrm{k}$ and $\tau_{2}$ ) of environmental factors on photosynthetic depression by $\mathrm{SO}_{2}$ (Kropff 1989a).

In the present study, the parameters $\mathrm{k}$ and $\tau_{2}$ were determined for all measured time series of photosynthesis separately. At $8^{\circ} \mathrm{C}$ and high PPFD, photosynthesis of the control plants showed a continuous decrease during the day. This was possibly due to photoinhibition, which is assumed to be based upon inactivation of the electron transport system in the thylakoids (Powles 1984, Öquist et al. 1987). Before model analysis, the data on photosynthesis of the fumigated plants at low temperature and low PPFD were corrected for the time trend in photosynthesis observed in the control plants.

\section{Detection of $S(I V)$ in leaves}

To verify conclusions from model analysis of gas exchange measurements at the biochemical level, S(IV) concentrations were analysed in leaves of $V$. faba after a $2 \mathrm{~h}$ fumigation period $\left(1200 \mu \mathrm{g} \mathrm{SO}_{2} \mathrm{~m}^{-3}\right)$. The West and Gaeke (1956) procedure for the determination of $\mathrm{SO}_{2}$ was adapted to plant tissue for this purpose following Miller and Xerikos (1979). Samples of leaves (10 g fresh weight) were immediately frozen and ground in liquid nitrogen. The powder was added to $100 \mathrm{ml} 0.2 \mathrm{M}$ TCM $(0.2 \mathrm{M} \mathrm{HgCl}$ and $0.4 \mathrm{M} \mathrm{NaCl})$ and the suspension was ultrasonically vibrated for $3 \mathrm{~min}$ and centrifuged at $12500 \mathrm{~g}$. Formaldehyde $(0.2 \mathrm{ml} 0.2 \%)$ and $0.5 \mathrm{ml}$ color solution $(0.48 \mathrm{~m} M$ pararosanaline in $1 \mathrm{~m} M$ phosphoric acid) were added to $1.8 \mathrm{ml}$ of the supernatant. The final $\mathrm{pH}$ of the solution was 1.2. After $25 \mathrm{~min}$ in the dark $\left(20^{\circ} \mathrm{C}\right)$ the absorbance was measured at $575 \mathrm{~nm}$. Standard additions of S(IV) to non-fumigated leaf material established the reliability of the technique and were
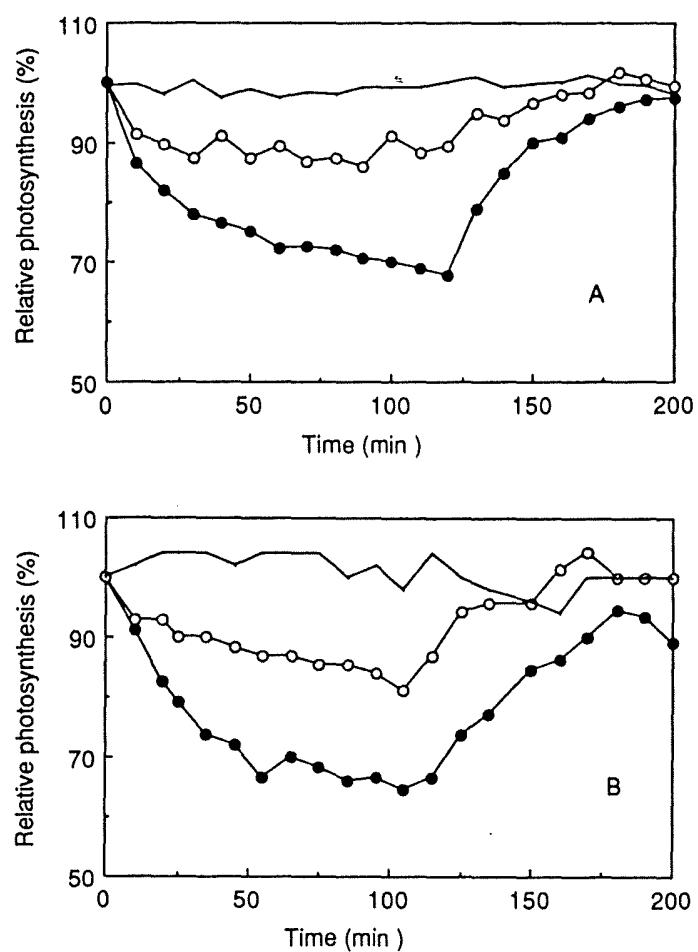

Fig. 1. Relative photosynthesis of Vicia faba leaves during a fumigation period of $120 \mathrm{~min}$ and a recovery period of $80 \mathrm{~min}$. (A), control $(-)$; fumigated with $1500 \mu \mathrm{g} \mathrm{SO}_{2} \mathrm{~m}^{-3.3}$ at $18^{\circ} \mathrm{C}$ and $30 \% \mathrm{RH}(\mathrm{O})$; fumigated with $1500 \mu \mathrm{g} \mathrm{SO}_{2} \mathrm{~m}^{-3}$ at $18^{\circ} \mathrm{C}$ and $70 \% \mathrm{RH}()^{\circ}$. (B), control (-); fumigated with $1000 \mu \mathrm{g} \mathrm{SO}$ $\mathrm{m}^{-3}$ at $18^{\circ} \mathrm{C}$ and $70 \% \mathrm{RH}(\mathrm{O})$; fumigated with $1000 \mu \mathrm{g} \mathrm{SO} \mathrm{m}^{-3}$ at $8^{\circ} \mathrm{C}$ and $70 \% \mathrm{RH}(\mathbf{0})$. 
Tab. 1. Experimental details on plants of the different treatments and results of the model analysis (averages \pm SE of mean).

\begin{tabular}{|c|c|c|c|c|c|c|}
\hline \multicolumn{7}{|l|}{ Treatments } \\
\hline Temperature $\left({ }^{\circ} \mathrm{C}\right)$ & 8 & 8 & 18 & 18 & 18 & 18 \\
\hline Radiation $\left(\mu \mathrm{mol} \mathrm{m}^{-2} \mathrm{~s}^{-1}\right)$ & 450 & 900 & 450 & 900 & 900 & 900 \\
\hline Relative humidity (\%) & 70 & 70 & 70 & 70 & 50 & 30 \\
\hline Number of replicates & 6 & 6 & 2 & 6 & 2 & 2 \\
\hline \multicolumn{7}{|l|}{ Results . } \\
\hline Photosynthesis at start of fumigation $\left(\mu \mathrm{g} \mathrm{CO}_{2} \mathrm{~m}^{-2} \mathrm{~s}^{-1}\right)$ & $401 \pm 45$ & $362 \pm 55$ & $672 \pm 26$ & $796 \pm 39$ & $591 \pm 54$ & $348 \pm 5$ \\
\hline Stomatal resistance at start of fumigation $\left(\mathrm{s} \mathrm{m}^{-1}\right)$ & $104 \pm 6$ & $125 \pm 18$ & $160 \pm 15$ & $107 \pm 8$ & $203 \pm 42$ & $194 \pm 26$ \\
\hline $\mathrm{SO}_{2}$ concentration $\left(\mu \mathrm{g} \mathrm{SO}_{2} \mathrm{~m}^{3}\right)$ & $869 \pm 79$ & $697 \pm 140$ & $1080 \pm 10$ & $1210 \pm 97$ & $1461 \pm 16$ & $1485 \pm 13.5$ \\
\hline Leaf thickness (mm) & $0.33 \pm 0.01$ & $0.34 \pm 0.01$ & $0.26 \pm 0.01$ & $0.26 \pm 0.01$ & $0.33 \pm 0.01$ & $0.33 \pm 0.03$ \\
\hline $\mathrm{SO}_{2}$ uptake rate at the end of fumigation $\left(\mu \mathrm{g} \mathrm{SO}_{2} \mathrm{~m}^{-2} \mathrm{~s}^{-1}\right)$ & $3.43 \pm 0.44$ & $2.60 \pm 0.38$ & $3.00 \pm 0.01$ & $4.73 \pm 0.43$ & $3.20 \pm 0.10$ & $3.35 \pm 0.25$ \\
\hline Relative photosynthesis (at the end of fumigation) & $53.3 \pm 7.7$ & $76.0 \pm 3.5$ & $79.5 \pm 1.5$ & $76.5 \pm 1.9$ & $88.0 \pm 7.0$ & $82.0 \pm 6.0$ \\
\hline$k\left(\mathrm{mmol} \mathrm{S}(\mathrm{IV}) \mathrm{I}^{-1}\right)^{-1}$ & $1.00 \pm 0.11$ & $0.77 \pm 0.07$ & $0.95 \pm 0.05$ & $0.88 \pm 0.05$ & $1.08 \pm 0.02$ & $0.98 \pm 0.06$ \\
\hline$\tau_{2}(\min )$ & $51.3 \pm 9.4$ & $47.0 \pm 10.6$ & $23.0 \pm 0.1$ & $21.2 \pm 1.9$ & $16.0 \pm 2.0$ & $16.5 \pm 3.5$ \\
\hline
\end{tabular}

used to calculate S(IV) concentrations in $\mu \mathrm{g}$ ( $\mathrm{g}$ fresh weight $)^{-1}$. Glutathione, which may accumulate after $\mathrm{SO}_{2}$ exposure (Maas 1987), did not interfere with the measurements, since it was stabilized by TCM at $\mathrm{pH}$ 1.2 .

\section{Results and discussion}

A higher relative humidity or a lower temperature resulted in stronger reductions in photosynthesis during a short fumigation period and a subsequent recovery period (Fig. 1). These data illustrate the generally observed pattern of photosynthesis during short fumigation experiments (Darrall 1986). Photosynthesis quickly decreased after the onset of fumigation, followed by a stabilization within $2 \mathrm{~h}$ of fumigation and a recovery when fumigation was stopped. Generally, the depression of photosynthesis was more severe at higher humidity and at lower temperature (Tab. 1). Detailed information on photosynthesis, leaf thickness, $\mathrm{SO}_{2}$ concentration and uptake rate at the end of the fumigation period for the different treatments is given in Tab. 1.

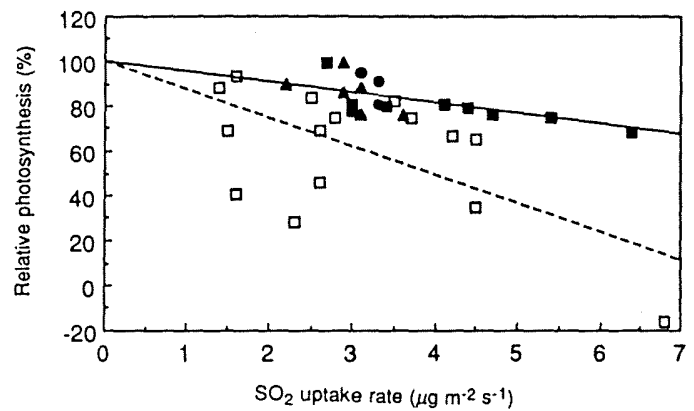

Fig. 2. Relative rate of photosynthesis of Vicia faba leaves after 120 min of $\mathrm{SO}_{2}$ exposure in relation to the rate of $\mathrm{SO}_{2}$ uptake ( $F$ in $\mu \mathrm{g} \mathrm{m}^{-2} \mathrm{~s}^{-1}$ ) for plants fumigated at $18^{\circ} \mathrm{C}$ and $30 \% \mathrm{RH}$ $(\Delta), 50 \% \mathrm{RH}(\mathbf{O})$ and $70 \% \mathrm{RH}(\boldsymbol{\square})$. Relative photosynthesis $\left(18^{\circ} \mathrm{C}\right)(\%)=100-4.7 F ; r^{2}=0.46, \mathrm{n}=18$ (solid line) and plants fumigated at $8^{\circ} \mathrm{C}(\square)$; Relative photosynthesis $\left(8^{\circ} \mathrm{C}\right)$ $(\%)=100-12.7 F ; r=0.35, \mathrm{n}=15$ (broken line).

\section{The effect of humidity}

At $18^{\circ} \mathrm{C}$ a linear relation [with a slope of $4.7\left(\mu \mathrm{g} \mathrm{SO}_{2}\right.$ $\left.\mathrm{m}^{-2} \mathrm{~s}^{-1}\right)^{-1}$ ] was observed between the rate of $\mathrm{SO}_{2}$ uptake and relative photosynthesis $2 \mathrm{~h}$ after the onset of fumigation. No effect of humidity $(30-70 \% \mathrm{RH})$ on the relation between the rate of $\mathrm{SO}_{2}$ uptake and relative photosynthesis was found at $18^{\circ} \mathrm{C}$ (Fig. 2, closed symbols). However, the rate of $\mathrm{SO}_{2}$ uptake was generally higher at a higher humidity, resulting in stronger reductions in photosynthesis (Tab. 1). This was caused by the lower stomatal resistance at high humidity (Tab. 1). This difference was only clear for the $70 \% \mathrm{RH}$ treament vs the 30 and $50 \%$ RH treatments. Similar conclusions were drawn from preliminary experiments at the same conditions in the equipment for routine measurement of photosynthesis at the Centre for Agrobiological Research (data not shown). These results (Fig. 2) indicate that the influence of humidity on photosynthetic effects of $\mathrm{SO}_{2}$ is a result of humidity effects on stomatal opening and thus the uptake of $\mathrm{SO}_{2}$, but not a result of influences on the biochemical processes.

The significant role of humidity in plant responses to $\mathrm{SO}_{2}$ was demonstrated earlier by McLaughlin and Taylor (1981). The effect of air humidity on the rate of $\mathrm{SO}_{2}$ uptake can be easily understood from the response of stomata to humidity. Stomatal behaviour can be characterized by the ratio between internal and ambient $\mathrm{CO}_{2}$ concentration $\left(C_{i}\right.$ and $C_{a}$, respectively), which tends to be constant over a wide range of conditions in many

Tab. 2. The effect of humidity ( $\mathrm{RH}$ in \%) and vapour pressure deficit (VPD, mbar) on the ratio between internal $\left(\mathrm{C}_{\mathrm{i}}\right)$ and ambient $\left(\mathrm{C}_{\mathrm{a}}\right) \mathrm{CO}_{2}$ concentration at high radiation levels, $\mathrm{n}$ is number of replicates.

\begin{tabular}{rccrc}
\hline $\mathrm{n}$ & $\begin{array}{c}\text { Temper- } \\
\text { ature }\left({ }^{\circ} \mathrm{C}\right)\end{array}$ & $\mathrm{RH}(\%)$ & $\begin{array}{c}\mathrm{VPD} \\
(\mathrm{mbar})\end{array}$ & $\mathrm{C}_{\mathrm{i}} / C_{\mathrm{a}}$ \\
\hline 12 & 8 & 70 & 3.3 & $0.89 \pm 0.02$ \\
6 & 18 & 70 & 6.2 & $0.76 \pm 0.02$ \\
2 & 18 & 50 & 10.3 & $0.66 \pm 0.03$ \\
2 & 18 & 30 & 14.4 & $0.71 \pm 0.03$ \\
\hline
\end{tabular}




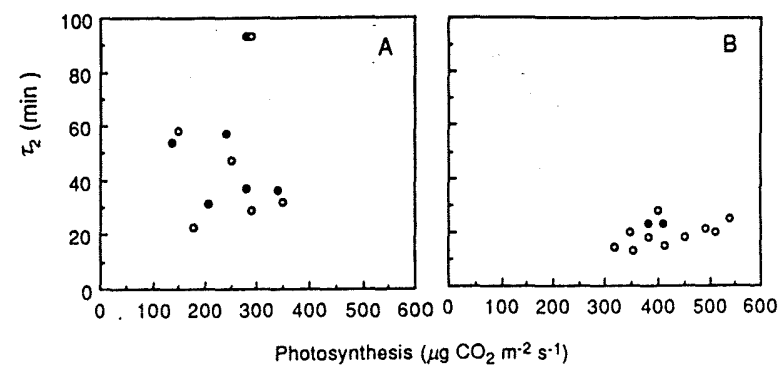

Fig. 3. Relation between the time coefficient for S(IV) oxidation $\left(\tau_{2}, \mathrm{~min}\right)$ as determined by model analysis and the rate of photosynthesis at the onset of fumigation at $8^{\circ} \mathrm{C}(\mathrm{A})$ and $18^{\circ} \mathrm{C}(\mathrm{B})$. Data were obtained at a PPFD of $900 \mu \mathrm{mol} \mathrm{m} \mathrm{m}^{-2} \mathrm{~s}^{-1}$ (O) and a PPFD of $450 \mu \mathrm{mol} \mathrm{m} \mathrm{m}^{-2} \mathrm{~s}^{-1}(\mathbf{O})$.

plant species (Goudriaan and van Laar 1978, Wong et al. 1979), although it varies with humidity (Tab. 2; Morison 1987, Losch and Tenhunen 1981). At 70\% RH, the ratio was much higher at low than at high temperature (Tab. 2). This confirms the observation that VPD (vapour pressure deficit), instead of relative humidity is the driving power behind stomatal reactions to humidity (Morison 1987).

\section{The effect of temperature}

Photosynthetic depression at the end of the fumigation period at a given rate of $\mathrm{SO}_{2}$ uptake was much stronger at $8^{\circ} \mathrm{C}$ when compared to leaves exposed to $\mathrm{SO}_{2}$ at $18^{\circ} \mathrm{C}$ (Fig. 2). This effect can only be explained by an influence of $\mathrm{SO}_{2}$ on biochemical processes responsible for photosynthetic depression by $\mathrm{SO}_{2}$. The effect is either due to an increased sensitivity of photosynthesis to $S$ (IV) metabolites or to a reduced rate of S(IV) oxidation. The slope of this line can be expressed in terms of the model by the product of the sensitivity parameter $\mathrm{k}$ and the time coefficient for S(IV) oxidation $\tau_{2}$ (Kropff 1989b).

The effect of temperature over all treatments on the parameters $k$ and $\tau_{2}$ was estimated by model analysis of the data for each plant, using measured data on leaf thickness and rate of photosynthesis and stomatal resistance before fumigation of the individual plants (Kropff 1989b). This procedure enables the estimation of temperature effects on biochemical processes determining photosynthetic reduction by $\mathrm{SO}_{2}$, independently of stomatal responses to humidity or of interplant variability in stomatal opening. The time coefficient for S(IV) oxidation $\left(\tau_{2}\right)$ was a factor 2.5 higher at the low temperature $\left(20 \mathrm{~min}\right.$ at $18^{\circ} \mathrm{C}$ and $49 \mathrm{~min}$ at $\left.8^{\circ} \mathrm{C}\right)$, while the sensitivity parameter $(\mathrm{k})$ was not significantly affected by temperature $\left[1.80\left(\mathrm{mmol} \mathrm{S}(\mathrm{IV}) \mathrm{I}^{-1}\right)^{-1}\right.$ at $18^{\circ} \mathrm{C}$ and $1.01\left(\mathrm{mmol} \mathrm{S}(\mathrm{IV}) \mathrm{1}^{-1}\right)^{-1}$ at $8^{\circ} \mathrm{C}$. The value for the sensitivity parameter $\mathrm{k}$, ca 1 (mmol S(IV) $\left.1^{-1}\right)^{-1}$ (Tab. 1) was very close to the value determined from experimental data of Alscher et al. (1987) and Sakaki and Kondo (1985) by Kropff (1989a), which was 0.825 $\left(\mathrm{mmol} S(\mathrm{IV}) \mathrm{1}^{-1}\right)^{-1}$. An increase in the slope relating
$\mathrm{SO}_{2}$ uptake to relative photosynthesis by a factor 2.5 was expected, because this slope is proportional to $k \tau_{2}$. This is close to the factor 2.7, which was observed (Fig. 2 ). More detailed information on the model parameters, estimated for the different treatments is given in Tab. 1.

No effect of humidity on the biochemical parameters was found at $18^{\circ} \mathrm{C}$ (Tab. 1), indicating that humidity only affected photosynthetic depression by $\mathrm{SO}_{2}$ through its effect on stomatal resistance.

This analysis indicates that higher sensitivity of the plants to $\mathrm{SO}_{2}$ at $8^{\circ} \mathrm{C}$ (Fig. 2) was caused by the stronger accumulation of S(IV) as a result of a slower rate of S(IV) oxidation. S(IV) measurements in leaves of $V$. faba, exposed to $1200 \mu \mathrm{g} \mathrm{SO} \mathrm{m}^{-3}$ for $2 \mathrm{~h}$ at 7 and $20^{\circ} \mathrm{C}$ showed a stronger accumulation of S(IV) in the leaves at the lower temperature $\left(98 \pm 4\right.$ and $23 \pm 2 \mu \mathrm{g} \mathrm{g}^{-1}$ respectively). S(IV) concentration is a factor 4.3 higher at $7^{\circ} \mathrm{C}$ than in leaves exposed at $20^{\circ} \mathrm{C}$. This is higher than the factor 2.5 derived from the model analysis. This may be partly explained by the greater difference in temperature between the treatments. Another reason for the difference may be that for S(IV) measurements five leaf layers were sampled from the plants, which differed in age in order to obtain enough material for chemical analysis, whereas the youngest fully unfolded leaves were used in the gas exchange measurements.

No effect of radiation level on $\tau_{2}$ was observed at the low temperature (Tab. 1). In the plants exposed at low temperature and high radiation a continuous decrease of photosynthesis over the day was observed. Because this effect was not observed in the plants exposed at low temperature and low radiation (which was light saturating) this effect was assumed to be the result of photoinhibition, which is thought to be the result of the formation of active oxygen species due to inhibition of the electron transport (Powles 1984, Öquist et al. 1987). The absence of an effect on $\tau_{2}$ is interesting, because active oxygen species should enhance the oxidation rate of S(IV). Although the data on photosynthesis of the plants exposed at low temperature and high radiation had to be corrected for the time course of photosynthesis in the control plants, the estimated values of the parameters are in the same range as the values estimated from plants exposed at low temperature and low (but saturating) radiation (Tab. 1). Further causal interpretation of the results from the photoinhibited plants requires more research at the biochemical level.

Davies (1980) found a stronger effect of $\mathrm{SO}_{2}$ on plant growth at low radiation levels, which was suggested to be the result of a lowered rate of S(IV) oxidation due to a reduced assimilate supply. However, no relationship was found between the rate of net photosynthesis at the beginning of the fumigation period and $\tau_{2}$ (Fig. 3).

Stomatal responses to $\mathrm{SO}_{2}$-induced changes in photosynthesis were small in plants fumigated at $8^{\circ} \mathrm{C}$, which resulted in an increase in $\mathrm{C}_{\mathrm{i}} / \mathrm{C}_{\mathrm{a}}$ throughout the fumigation period. This effect is important when $\mathrm{SO}_{2}$ exposure 


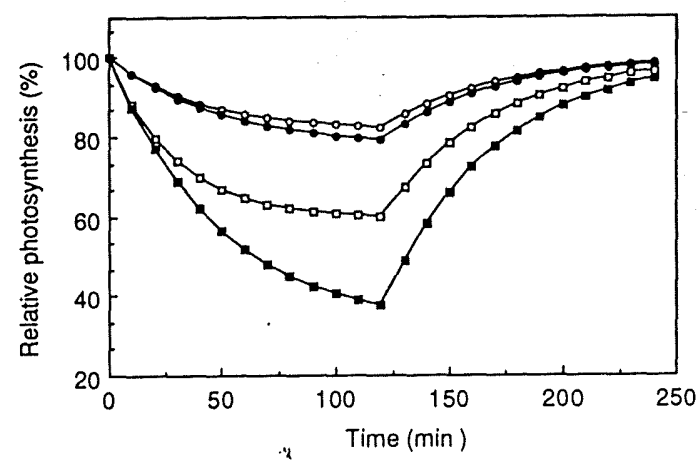

Fig. 4. Simulated effect of $\mathrm{SO}_{2}$ on relative photosynthesis during a fumigation period of $120 \mathrm{~min}$ and a subsequent recovery period of $120 \mathrm{~min}$ at $8^{\circ} \mathrm{C}$; leaves exposed to $400 \mu \mathrm{g} \mathrm{SO}_{2} \mathrm{~m}^{-3}$ with stomatal feedback $(O)$ and without stomatal feedback (O): leaves exposed to $1200 \mu \mathrm{g} \mathrm{SO}_{2} \mathrm{~m}^{-3}$ with stomatal feedback ( $\square$ ) and without stomatal feedback ( $\mathbf{\square})$. Leaf characteristics obtained from the experimental data of Vicia faba leaves.

results in severe reductions in photosynthesis, because the rate of $\mathrm{SO}_{2}$ uptake is much higher when stomata do not close as a result of a decreasing photosynthesis. An illustration of this phenomenon is given in Fig. 4, where the modelled effect of 400 and $1200 \mu \mathrm{g} \mathrm{SO}_{2} \mathrm{~m}^{-3}$ on leaf photosynthesis is presented for a leaf in which the stomata respond to the lowered rate of photosynthesis, and for a leaf in which stomatal conductance remains unchanged. The effects of $\mathrm{SO}_{2}$ are much more severe when the stomata do not close as a result of the reduced rates of photosynthesis when photosynthetic depression is high.

\section{Implications for plant growth}

Most studies in which the effect $\mathrm{SO}_{2}$ on photosynthesis is analysed, reported very small or no effects of $\mathrm{SO}_{2}$ at low concentrations (()-40) $\mu \mathrm{g} \mathrm{SO}_{2} \mathrm{~m}^{-3}$; Darrall 1989). However, the data presented in this study demonstrate that reduced photosynthesis may occur at these low concentrations in winter periods when the temperatures are low. When the results obtained in this study are extrapolated to low concentrations, a photosynthetic reduction of $5.5 \%$ is expected at $8^{\circ} \mathrm{C}$ at $100 \mu \mathrm{g} \mathrm{SO}_{2} \mathrm{~m}^{-3}$ (uptake $0.5 \mu \mathrm{g} \mathrm{SO}_{2} \mathrm{~m}^{-2} \mathrm{~s}^{-1}$; Fig. 2). However, since the values for $\tau$, showed a large variation (from 23 to $93 \mathrm{~min}$ at $8^{\circ} \mathrm{C}$ ), the expected range of photosynthetic reductions for the plants used in this study at $8^{\circ} \mathrm{C}$ exposed to $100 \mu \mathrm{g} \mathrm{SO}_{2} \mathrm{~m}^{-3}$ is $2-10 \%$.

The results presented in this study may explain the severe effects of $\mathrm{SO}_{2}$ on plant growth in winter conditions, observed in many studies (Cowling and Lockyer 1978, Davies 1980, Baker et al. 1982, Whitmore and Mansfield 1983, Baker et al. 1986). Besides low temperatures, low radiation levels also reduce the rate of S(IV) oxidation in plant material (Rothermel and Alscher 1985), possibly explaining the extreme effect of low radiation on plant growth described by Davies (1980).

When plants with thin leaves and a low capacity for
$\mathrm{S}$ (IV) oxidation are exposed to low $\mathrm{SO}_{2}$ concentrations at low temperatures, significant reductions in photosynthesis have to be expected. The approach presented in this paper may help to quantify growth depressions in plants exposed to $\mathrm{SO}_{2}$ during winter conditions, by incorporation of the submodel for $\mathrm{SO}_{2}$ effects on leaf photosynthesis in crop growth models (Kropff and Goudriaan 1989, Kropff 1990).

Acknowledgements - This work was supported by the Dutch Priority Programme on Acidification. We thank C. T. de Wit, E. H. Adema, J. Goudriaan, H. H. van Laar and D. W. G. van Kraalingen for helpful discussions and comments on the manuscript.

\section{References}

Alscher, R., Bower, J. L. \& Zipfel, W. 1987. This basis for different sensitivities of photosynthesis to $\mathrm{SO}_{2}$ in two cultivars of pea. - J. Exp. Bot. 38: 99-108.

Baker, C. K., Unsworth, M. H. \& Greenwood, P. 1982. Leaf injury on wheat plants exposed in the field in winter to $\mathrm{SO}_{2}$. - Nature 299: 149-151.

- , Colls, J. J., Fullwood, A. E. \& Seaton, G. G. R. 1986. Depression of growth and yield in winter barley exposed to sulphur dioxide in the field. - New Phytol. 104: 233-241.

- , Fullwood, A. E. \& Colls, J. J. 1987. Tillering and leaf area of winter barley exposed to sulphur dioxide in the field. New Phytol. 107: 373-385.

Cowling, D. W. \& Lockyer, D. R. 1978. The effect of $\mathrm{SO}_{2}$ on Lolium perenne $\mathrm{L}$. grown at different levels of sulphur and nitrogen nutrition. - J. Exp. Bot. 29: 257-265.

Darrall, N. M. 1986. The sensitivity of net photosynthesis in several plant species to short-term fumigation with sulphur dioxide. - J. Exp. Bot. 37: 1313-1322.

- 1989. The effect of air pollutants on physiological processes in plants. - Plant Cell Environ. 12: 1-30.

Davies, T. 1980. Grasses more sensitive to $\mathrm{SO}_{2}$ pollution in conditions of low irradiance and short days. - Nature 284: $483-485$.

Goudriaan, J. \& van Laar, H. H. 1978. Relations between leaf resistance, $\mathrm{CO}_{2}$-concentration and $\mathrm{CO}_{2}$-assimilation in maize, beans, lalang grass and sunflower. - Photosynthetica 12: $241-249$.

Hällgren, J.-E. 1984. Photosynthetic gas exchange in leaves affected by air pollutants. - In Gaseous Air Pollutants and Plant Metabolism (M. J. Koziol and F. R. Whatlcy, eds), pp. 147-159. Butterworths, London. ISBN (0-408-11152-6.

Hove, L. W. A. van, Tonk, W. J. M., Pieters, G. A., Adema, E. H. \& Vredenberg, W. J. 1988. A leaf chamber for measuring the uptake of pollutant gases at low concentrations by leaves, transpiration and carbon dioxide assimilation. - Atmospheric Environ. 22: 2515-2523.

Kropff, M. J. 1987. Physiological effects of sulphur dioxide. I. The effect of $\mathrm{SO}_{2}$ on photosynthesis and stomatal regulation of $V$. faba L. - Plant Cell Environ. 10: 753-760.

- 1989a. Modelling short term effects of sulphur dioxide. I. A model for the flux of $\mathrm{SO}_{2}$ into leaves and effects on leaf photosynthesis. - Neth. J. Plant Pathol. 95: 195-213.

- 1989b. Modelling short term effects of sulphur dioxide. II Quantification of biochemical characteristics determining the effect of $\mathrm{SO}_{2}$ on photosynthesis of leaves. - Neth. J. Plant Pathol. 95: 214-224.

- 1990. The effects of long term open air fumigation with $\mathrm{SO}_{2}$ on a field crop of broad beans ( $V$. faba L). III. Quantitative analysis of damage components. - New Phytol. 115: 357365.

- \& Goudriaan, J. 1989. Modelling short term effects of sulphur dioxide. III. The effect of SO, on photosynthesis of leaf canopies. - Neth. J. Plant Pathol. 95: 265-280. 
Losch, R. \& Tenhunen, J. D. 1981. Stomatal responses to humidity - phenomenon and mechanism. - In Stomatal Physiology (P. G. Jarvis and T. A. Mansfield, eds), pp. 137-161. Cambridge University Press, Cambridge. ISBN ()-521-28151-2.

Maas, F. A. 1987. Responses of plants to sulphur containing air pollutants $\left(\mathrm{H}_{2} \mathrm{~S}\right.$ and $\left.\mathrm{SO}_{2}\right)$. Ph. D. thesis, University of Groningen, The Netherlands, p. 110.

Martin, L. R. 1984. Kinetic studies of sulfite oxidation in aqueous solution. - In $\mathrm{SO}_{2}, \mathrm{NO}$ and $\mathrm{NO}$, Oxidation Mechanisms: Atmospheric Considerations (J. G. Calvert, ed.), pp. 63-100. Butterworths Publishers, Boston-London. ISBN $0-250-40568-7$.

McLaughlin, S. B. \& Taylor, G. E. 1981. Relative humidity: Important modifier of pollutant uptake by plants. - Science 211: 167 .

Miller, J. E. \& Xerikos, P. B. 1979. Residence time of sulphite in $\mathrm{SO}_{2}$ 'sensitive' and 'tolerant' soybean cultivars. - Environ. Pollut. (Ser. A) 18: 259-264.

Morison, J. I. L. 1987. Intercellular CO, concentration and stomatal response to $\mathrm{CO}_{2}$. - In Stomatal Function (E. Zeiger and G. D. Farquhar, eds), pp. 229-251. Stanford University press, Stanford, CA. ISBN 0-8047-1347-2.

Öquist, G., Greer, D. H. \& Ögren, E. 1987. Light stress at low temperature. - In Photoinhibition (D. J. Kyle, C. B. Osmond and C. J. Arntzen, eds). pp. 67-87. Elsevier Science Publishers, London. ISBN 0-444-80890-6.

Powles, S.B. 1984. Photoinhibition of photosynthesis induced by visible light. - Annu. Rev. Plant Physiol. 35: 15-44.

Rothermel, B. \& Alscher, R. 1985. A light-enhanced metabo- lism of sulfite in cells of Cucumis sativus L. cotyledons. Planta 166: 105-110.

Sakaki, T. \& Kondo, N. 1985. Inhibition of photosynthesis by sulfite in mesophyll protoplasts isolated from $V$. faba L. in relation to intracellular sulfite accumulation. - Plant Cell Physiol. 26: 1045-1055.

Unsworth, M. H., Biscoe, P. V. \& Black, V. 1976. Analysis of gas exchange between plants and polluted atmospheres. In Effects of Air Pollutants on Plants (T. A. Mansfield, ed.), pp. 7-16. Cambridge University Press, London. ISBN 0-521-21087-9.

- \& Ormrod, D. P. 1982. Effects of gaseous air pollution in agriculture and horticulture. Butterworths, London. p.532. ISBN 0-408-107505-7.

West, P. W. \& Gaeke, G. C. 1956. Fixation of sulfur dioxide as sulfitomercurate II and subsequent colorimetric estimation. - Anal. Chem. 28: 1816-1819.

Whitmore, M. E. \& Mansfield, T. A. 1983. Effects of longterm exposure to $\mathrm{SO}_{2}$ and $\mathrm{NO}_{2}$, on Poa pratensis and other grasses. - Environ. Pollut. (Ser. A) 31: 217-235.

Winner, W. E., Mooney, H. A. \& Goldstein, R. A. 1985. Sulfur dioxide and vegetation. Physiology, Ecology and Policy issues Stanford University Press, Stanford. CA p. 593. ISBN 0-8047-1234-4.

Wong, S. C., Cowan, I. R. \& Farquhar, G. D. 1979. Stomatal conductance correlates with photosynthetic capacity. $-\mathrm{Na}$ ture 282: $424-426$ 